\title{
ОГЛЯД МЕТОДІВ ТА МОДЕЛЕЙ ПОЛІМЕРАЗНО-ЛАНЦЮГОВОЇ РЕАКЦІї
}

\author{
А. С. Сверстюк, Т. В. Бігуняк, Б. О. Перевізник \\ ДВНЗ «Тернопільський державний медичний університет імені І. Я. Горбачевського \\ МОЗ України»
}

\begin{abstract}
Проведено огляд методів та моделей полімеразно-ланцюгової реакції для задачі математичного моделювання та оцінювання мінімально необхідного часу реалізації кожної стадії циклу, що в загальному випадку підвищить ефективність проведення досліджуваного методу молекулярної біології.
\end{abstract}

Ключові слова: полімеразно-ланцюгова реакція, методи полімеразно-ланцюгової реакції, математична модель полімеразно-ланцюгової реакції.

\section{ОБЗОР МЕТОДОВ И МОДЕЛЕЙ ПОЛИМЕРАЗНО-ЦЕПНОЙ РЕАКЦИИ}

\author{
А. С. Сверстюк, Т. В. Бигуняк, Б. О. Перевизнык \\ ГВУЗ «Тернопольский государственный медицинский университет \\ имени И. Я. Горбачевского мОЗ украины»
}

\begin{abstract}
Проведен обзор методов и моделей полимеразно-цепной реакции для задачи математического моделирования и оценки минимально необходимого времени реализации каждой стадии цикла, что в общем случае повысит эффективность проведения исследуемого метода молекулярной биологии.
\end{abstract}

Ключевые слова: полимеразная цепная реакция, методы полимеразной цепной реакции, математическая модель полимеразной цепной реакции.

\section{OVERVIEW OF METHODS AND POLYMERASE-CHAIN REACTION MODELS}

\section{A. S. Sverstyuk, T. V. Bihunyak, B. O. Pereviznyk \\ SHEI «Ternopil State Medical University by I. Ya. Horbachevsky of MPH of Ukraine»}

In the article overviewed the methods and polymerase chain reaction models for the mathematical modeling and evaluating minimum time required problem for of each stage of the cycle and showed how to increase the studied molecular biology techniques efficiency.

Key words: polymerase-chain reaction, methods of polymerase-chain reaction, mathematical model of polymerase-chain reaction.

Вступ. Полімеразна ланцюгова реакція (ПЛР або PCR) - експериментальний метод молекулярної біології, спосіб значного збільшення малих концентрацій бажаних фрагментів ДНК в біологічному матеріалі. Крім простого збільшення числа копій ДНК (цей процес називається ампліфікацією), ПЛР дозволяє проводити безліч інших маніпуляцій з генетичним матеріалом (введення мутацій, зрощення фрагментів ДНК), і широко використовується у біологічній та медичній практиці, наприклад для клонування генів, введення мутацій, виділення нових генів, секвенування, для створення і визначення генетично модифікованих організмів, діагностики захворювань (спадкових, інфекційних), ідентифікації малих кількостей ДНК, встановлення батьківства [1].
Для проведення ПЛР використовують ДНК-ампліфікатори, що забезпечують можливість програмування та підтримки оптимальної температури, необхідної для проходження процесів реакції (денатурація молекули ДНК, відпалювання з праймерами i синтез фрагмента ДНК) [2].

Виділення ДНК полягає в екстракції із матеріалу та виділенні чи нейтралізації домішок, які можуть зупиняти реакцію. Ампліфікація (природна реплікація ДНК in vitro) складаться iз трьох етапів, що проходять при різних температурних режимах:

- денатурація (розплітання спіралі ДНК і розходження ниток, здійснюеться при температурі 93$\left.95^{\circ} \mathrm{C}\right)$;

\footnotetext{
( А. С. Сверстюк, Т. В. Бігуняк, Б. О. Перевізник
} 


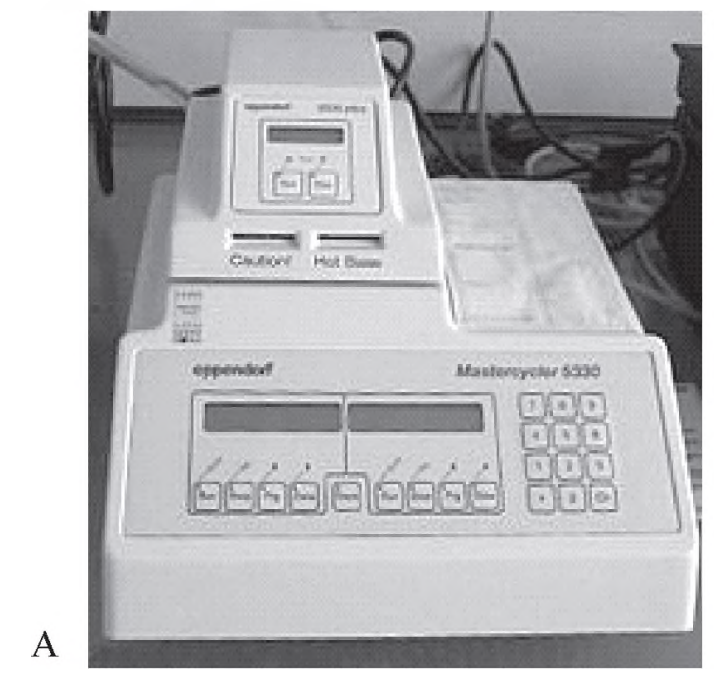

Puc. 1. Полімеразна ланцюгова реакція: А - типовий ампліфікатор; Б - схема проведення.
• відпал (приєднання праймерів при температурі 50 $\left.65^{\circ} \mathrm{C}\right)$;

- синтез ДНК (комплементарне добудування обох ниток ДНК, при температурі 70-72 ${ }^{\circ} \mathrm{C}$ ). Матеріалом для синтезу нових ланцюгів служать дезоксирибонуклеозидтрифосфати, що додаються в розчин. Процес синтезу каталізується ферментом taq-ДНК-полімеразою.

Далі цикли повторюються знову - ланцюги, що утворилися в першому циклі ампліфікації ДНК, служать матрицями для другого циклу ампліфікації. За $30-40$ циклів у розчині накопичується близько $10^{8}$ молекул, що достатньо для візуальної детекції цього фрагмента за допомогою методу електрофорезу в агарозному гелі.

Для ефективного проведення ПЛР необхідно забезпечити багатостадійний циклічний режим зміни температури. Кожна стадія циклу (денатурація, відпал, елонгація (синтез)) повинна відбуватися при певних температурах та впродовж відповідного часу. В іншому випадку необхідних перетворень молекул ДНК може не відбутися. Таким чином задача математичного моделювання і відповідних розрахунків полягає в оцінюванні мінімально необхідного часу реалізації кожної стадії циклу, що в загальному випадку забезпечить досягнення мінімального часу проведення ПЛР.

Метою роботи $\epsilon$ проведення огляду методів та математичних моделей ПЛР для ефективнішого використання методів молекулярної біології.

У багатьох роботах [3-5] наведені різні моделі ПЛР, розглянемо як самі методи, так і математичні моделі ПЛР.

Методи ПЛР. Пресимптоматична діагностика за допомогою ПЛР. Пресимптоматична діаг- ностика спадкових захворювань за допомогою ПЛР відкриває нові можливості превентивного (попереджувального) лікування (наприклад, порушення міді при хворобі Вільсона-Коновалова). Пренатальна діагностика дітей із тяжкими спадковими захворюваннями (міодистофія Дюшена, муковісцидоз, міотонічна дистрофія) дозволяє сім'ям, які мають уже хвору дитину, надіятися народити здорову дитину. Жінки - носії патогенного гена (підтвердженого ДНК-діагностикою), коли вірогідність народження хворої дитини (наприклад, гемофілія А та В) становить $50 \%$, при проведенні пренатальної діагностики (амніоцентез, кордоцентез із подальшою ДНК-діагностикою) можуть мати можливість народжувати здорову дитину.

Метод ДНК-чіпів. Для масового сканування поширених мутацій використовується метод ДНК-чіпів. В основі методу лежить принцип комплементарної гібридизації. Комплементарна гібридизація умовно складається 3 чотирьох кроків:

- визначення хімічної структури фрагмента ДНК;

- видалення фрагмента ДНК, який розміщується в рідинному субстраті у відповідному довідковому сегменті;

- вивчення невідомого матеріалу. Дослідний зразок ДНК вноситься в довідковий сегмент, який містить відомий фрагмент ДНК і при збігові структури здійснюється гібридизація;

- ідентифікація результату з допомогою різноманітних світлочутливих хімічних речовин.

ДНК-чіп являє собою пластинку площею близько $1 \mathrm{~cm}^{2}$, на якій у чітко визначеному порядку розміщені комірчини, кожна з яких містить одноланцюгові полінуклеотиди однієї визначеної послідовності основ. При цьому розроблені методики, коли олігонуклеотиди 
синтезуються безпосередньо на поверхні чіпа. 3'явилася можливість розмістити на 1 см$^{2}$ їх кілька мільйонів.

Постійно здійснюсться удосконалення ДНК-чіпів. Розроблені та застосовуються ДНК-чіпи для діагностики таласемій, муковісцидозу, раку молочної (грудної) залози, спадкової схильності до наркоманії, менінгітів та різноманітних інфекційних хвороб. Розроблені методики комбінації ДНК-чіпів та ПЛР. Це дало можливість розширити діагностичні можливості методу та прискорити процес ідентифікації.

Молекулярно-генетичні методи. Молекулярно-генетична діагностика спадкових хвороб використовується і для вивчення геному людини. Щоб виявити необхідні для цього специфічні фрагменти ДНК використовують блот-гібридизацію за Саузерном. Щоб виявити потрібні фрагменти, здійснюють гібридизацію ДНК-зондом або клонування фрагментом ДНК. Результат гібридизації комплементарних ланцюгів радіоактивного фрагмента ДНК знаходять за допомогою радіоавтографії (ДНК проявлясться у вигляді радіоактивної смуги). За допомогою методу Саузерна можна скласти карту геному на ділянці досліджуваного гена та встановити наявність мутації.

Методи мультиплексних ПЛР. Мультиплексні ПЛР використовують для визначення делецій у гені дистрофіну, на частку яких припадас $60 \%$ усіх мутацій, які спричиняють дистрофію Дюшена. Методика базується на ампліфікації фрагментів різних екзонів гена, в яких найчастіше виникають делеції. Якщо делеції відсутні, фрагмети ДНК зафарбовуються рівномірно, якщо ж у досліджуваній ДНК деякі екзони делетовані, то на електрофореграмі будуть відсутні фрагменти відповідних екзонів [6, 7]. Недоліком методу с те, що він не виявляє делеції, що перебувають в гетерозиготному стані або локалізовані в аутосомних генах [7].

ПЛР застосовують у дослідженнях 3 молекулярної біології пухлин. Зокрема, була підтверджена асоціація між HTLV-1 та Т-клітинним лейкозом дорослих і спастичним парапарезом, доведений зв'язок між вірусами папіломи людини 16 та 18 типів і карциномою шийки матки, показана роль мутацій ряду проонкогенів в канцерогенезі [8].

Метод генетичних відбитків пальців. Метод генетичних відбитків пальців (англ. genetic fingerprinting) використовується в криміналістиці для ідентифікації людини, порівнюючи ії ДНК з ДНК в наданому зразку. Із застосуванням ПЛР теоретично потрібна лише одна молекула ДНК для певної ідентифікації, хоча у окремих випадках саме ця чут- ливість збільшує ризик помилок через можливе забруднення, і ампліфікацію в результаті ДНК 3 зовнішніх джерел. Існус кілька методів генетичних відбитків пальців, але всі вони звичайно використовують гелевий електрофорез, після чого зразок фарбується за допомогою етідіум броміду або інших фарбників, або спостерігається за допомогою гібридизації з пробами ДНК за допомогою саузерн-блоттингу (англ. Southern blot). На практиці необхідний зразок генетичного матеріалу збирасться 3 місця злочину - кров, слина, сперма, волосся тощо. Цей зразок порівнюють 3 генетичним матеріалом підозрюваного. Оскільки є невелика вірогідність, що у двох людей відбитки виявляться схожими, цей метод частіше використовусться для доказу невинності підозрюваного. Хоча «генетичні відбитки пальців» унікальні (за винятком випадку однояйцевих близнят), споріднені зв' язки все ж таки можна встановити, зробивши декілька таких відбитків (рис. 2). Той же метод можна застосовувати, злегка модифікувавши його, для встановлення еволюційної спорідненості серед організмів [4].

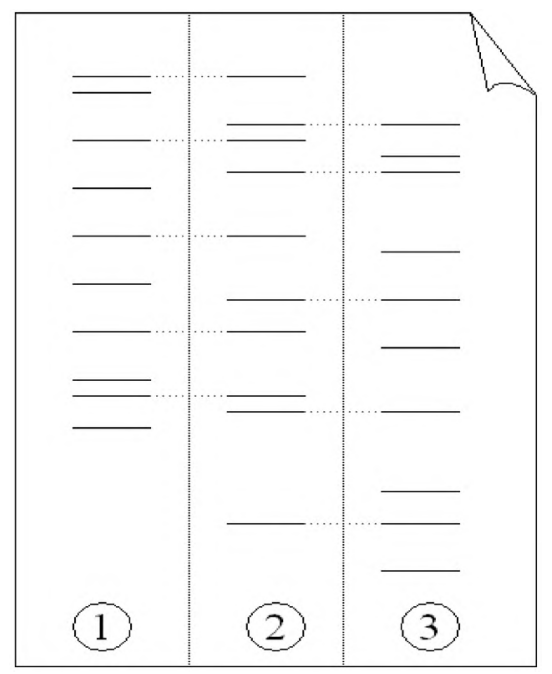

Puc. 2. Електрофорез фрагментів, ампліфікованих за допомогою ПЛР:

(1) - батько; (2) - дитина; (3) - мати.

Дитина набула деякі, але не всі, лінії своїх генетичних відбитків пальців від кожного із своїх батьків, створюючи новий унікальний набір.

Математична модель стадій ПЛР. У роботі [5] розглядається модель ПЛР стадії відпалу та елонгації.

Для стадії відпалу система диференціальних рівнянь має вигляд: 


$$
\begin{aligned}
& \frac{d s}{d t}=-k_{1} s p \\
& \frac{d p}{d t}=-k_{1} s p \\
& \frac{d s^{\prime}}{d t}=+k_{1} s p
\end{aligned}
$$

У формулах (1-3): $s$ - одноланцюгова ДНК, $p-$ молекула праймер, $s^{\prime}$ - одноланцюгова ДНК, зв' язана з праймером, $k_{1}$ - зворотна швидкість реакції для відпалу.

Модель стадії елонгації ПЛР, запропонована в роботі [5], має вигляд:

$$
\begin{gathered}
\frac{d s^{\prime}}{d t}=-k_{2} s^{\prime} q+k_{-2} c \\
\frac{d q}{d t}=-k_{2} s^{\prime} q+k_{-2} c+k_{3} c n \\
\frac{d c}{d t}=k_{2} s^{\prime} q-k_{-2} c-k_{3} c n \\
\frac{d n}{d t}=-k_{3} c n \\
\frac{d d}{d t}=k_{3} c n
\end{gathered}
$$

Тут $k_{-2} ; k_{2}-$ пряма i зворотна швидкості реакції для утворення комплексу, $q$ - Таq молекула, $c$ - число копій, $n$-нуклеотидна послідовність для елонгації, $k_{-3} ; k_{3}-$ пряма і зворотна пшвидкості реакції для елонгації, $d-$ дволанцюгова ДНК.

Для оцінювання мінімально необхідного часу реалізації кожної стадії циклу керуючим впливом $є$ температура, яка не врахована для вищенаведених моделей стадії відпалу та елонгації.

\section{Література}

1. Полімеразна ланцюгова реакція [Електронний ресурс]. - Режим доступу: http://uk.wikipedia.org/wiki/Полімеразна_ланцюгова_реакція

2. Гречаніна О. Я. Медична генетика : підручник / Кол. авт.; за ред. О. Я. Гречаніної, Р. В. Богатирьової, О. П. Волосовця. - К. : Медицина, 2007. $-536 \mathrm{c}$.

3. Arnheim N. Polymerase chain reaction strategy / N.Arnheim // Annual review of biochemistry. - 1992. - Vol. 61, XIV+1359.P. 131-156.

4. Xiangchun X. Thermal end effects on electroosmotic flow in capillary / X. Xiangchun, D. Sinton, L. Dongqing // Int. J. of Heat and Mass transfer. - 2004. - Vol. 47. - P. 3145-3157.
Висновки. У результаті огляду методів ПЛР можна зробити висновок, що це високоспецифічна і чутлива реакція, оскільки дає можливість досліджувати навіть одиночну копію гена у вихідному матеріалі. Методи ПЛР є оригінальними та особливими щодо застосування. Зокрема, мультиплексну ПЛР використовують для визначення делецій, що перебувають у гомозиготному стані у хворих з генними захворюваннями, метод ДНК-чіпів (array based analysis) дає змогу проводити масове сканування поширених мутацій, які є однонуклеотидними замінами (SNP) для різних скринінгових програм, що є продовженням програми «Геном людини».

При проведенні аналізу моделі ПЛР можна зробити висновок, що для оцінювання мінімально необхідного часу реалізації кожної стадії циклу керуючим впливом $є$ температура, яка не врахована в розглянутих моделях. У подальших дослідженнях потрібно дослідити питання щодо керованості стадії ПЛР 3 врахуванням температури та провести відповідне чисельне обчислення оптимального керування.

Таким чином, ПЛР є унікальним методом дослідження $з$ широкими можливостями застосування. Вся процедура реакції піддається автоматизації, що дозволяє отримувати достовірні результати.

На сьогодні основними принципами вдосконалення ПЛР є:

1) перехід від рідких середовищ до гелів, емульсій, твердої фази (скло, полімери);

2) перехід до багатокомпонентного аналізу, як за рахунок введення різних барвників, так і за рахунок паралельного проведення багатьох реакцій;

3) підвищення експресності визначення за рахунок проточних систем та / або мініатюризації реакційного об'єму, що значно зменшує час аналізу;

4) використання мікрочіпових технологій;

3) використання новітніх обчислювальних технологій, що забезпечують надійність кількісного аналізу.

5. Stone E.A multi-stage model for quantitative PCR / E. Stone, J. Goldes, M. Garlick // Mathematical Biosciences and Engineering. - Vol. 00. - P. 1-17.

6. Бочков Н. И. Клиническая генетика / Н. И. Бочков. -2-е изд., перераб. и доп. - М. : ГЭОТАР-МЕД, 2001. - 448 с.

7. Гринио Л. П. Дюшеновская миодистрофия / Л. П. Гринио // Изд. НМГА., 1998 - 190 с.

8. Дьяченко А. Г. Полимеразная цепная реакция. Достижения и проблемы / А. Г. Дьяченко, П. А. Дьяченко // Вісник Сумського державного університету - 2002. - № 8 (41). C. $12-17$. 